\title{
Use of otolith Sr:Ca ratios to study the riverine migratory behaviors of Japanese eel Anguilla japonica
}

\author{
W. N. Tzeng ${ }^{1, *}$, J. C. Shiao' ${ }^{1}$ Y. Iizuka ${ }^{2}$ \\ ${ }^{1}$ Department of Zoology, College of Science, National Taiwan University, Taipei 10617, Taiwan, ROC \\ ${ }^{2}$ Institute of Earth Science, Academic Sinica, Nankang, Taipei 11529, Taiwan, ROC
}

\begin{abstract}
To understand the migratory behavior and habitat use of the Japanese eel Anguilla japonica in the Kaoping River, SW Taiwan, the temporal changes of strontium (Sr) and calcium (Ca) contents in otoliths of the eels in combination with age data were examined by wavelength dispersive X-ray spectrometry with an electron probe microanalyzer. Ages of the eel were determined by the annulus mark in their otolith. The pattern of the Sr:Ca ratios in the otoliths, before the elver stage, was similar among all specimens. Post-elver stage Sr:Ca ratios indicated that the eels experienced different salinity histories in their growth phase yellow stage. The mean $( \pm \mathrm{SD}) \mathrm{Sr}$ :Ca ratios in otoliths beyond elver check of the 6 yellow eels from the freshwater middle reach were $1.8 \pm 0.2 \times 10^{-3}$ with a maximum value of $3.73 \times 10^{-3}$. Sr:Ca ratios of less than $4 \times 10^{-3}$ were used to discriminate the freshwater from seawater resident eels. Eels from the lower reach of the river were classified into 3 types: (1) freshwater contingents, Sr:Ca ratio $<4 \times 10^{-3}$, constituted $14 \%$ of the eels examined; (2) seawater contingent, Sr:Ca ratio $5.1 \pm 1.1 \times 10^{-3}(5 \%)$; and (3) estuarine contingent, Sr:Ca ratios ranged from 0 to $10 \times 10^{-3}$, with migration between freshwater and seawater $(81 \%)$. The frequency distribution of the 3 contingents differed between yellow and silver eel stages $(0.01<p<0.05$ for each case) and changed with age of the eel, indicating that most of the eels stayed in the estuary for the first year then migrated to the freshwater until $6 \mathrm{yr}$ old. The eel population in the river system was dominated by the estuarine contingent, probably because the estuarine environment was more stable and had a larger carrying capacity than the freshwater middle reach did, and also due to a preference for brackish water by the growth-phase, yellow eel.
\end{abstract}

KEY WORDS: Japanese eel $\cdot$ Anguilla japonica $\cdot$ Otolith microchemistry $\cdot$ Migratory behavior - Resale or republication not permitted without written consent of the publisher

\section{INTRODUCTION}

The Japanese eel Anguilla japonica is a catadromous fish. It is a panmictic population (Sang et al. 1994), spawning west of the Mariana Islands (Tsukamoto 1992), and growing in brackish estuaries and freshwater rivers and lakes in Taiwan, China, Korea and Japan in NE Asia (Tesch 1977). Their leaf-like larvae, leptocephali, drift with the North Equatorial Current and Kuroshio Current from oceanic spawning grounds to the continental shelf of Asian countries. After which, they metamorphose into transparent glass eels in the coastal waters and then become pigmented elvers in

*Email: wnt@ccms.ntu.edu.tw the estuary. The migration of eel larvae from the spawning ground to the estuary takes approximately 6 mo (Tzeng 1990, Tzeng \& Tsai 1994, Cheng \& Tzeng 1996). After upstream migration, the elvers become yellow eels and live in rivers for an average of 5 to $8 \mathrm{yr}$ (Tzeng et al. 2000a). At maturation, the yellow eels become silver eels and migrate to the spawning ground to spawn and die.

Recent studies have indicated that the life cycle of the eel may be over-simplified. The estuarine and freshwater migratory behavior of the eel may be more flexible and complicated than previously believed. Some European and Japanese eels may skip the freshwater life and live in marine coastal waters until maturation (Tsukamoto et al. 1998, Tzeng et al. 2000b, Tsu- 
kamoto \& Arai 2001). Jessop et al. (2002) also found that American eels in the growth phase yellow stage irregularly migrated between freshwater and estuary. Eels having different migratory behaviors in the yellow phase were classified into marine, estuarine and freshwater migratory contingents (Tzeng et al. 2003). The migratory contingents within a population were defined in studies of anadromous striped bass Morone saxatilis (Clark 1968, Secor 1999). The freshwater eel contingent has a well-known migratory pattern of growth in the river and migration downstream for spawning as silver eels. The marine eel contingent remains in coastal waters and never invades freshwater. The estuarine contingent migrates between freshwater and seawater. Whether the evolution of migratory contingents is genetically or environmentally determined is not clear. The degree of contribution by the freshwater contingent to the spawning stock is controversial (Tsukamoto et al. 1998, Limburg et al. 2002). Marking studies have been widely used to trace the migration of the eel (Gunning \& Shoop 1962, Liew 1982, Helfman et al. 1983, 1984, LaBar \& Facey 1983, Berg 1986, Westin 1990, McGovern \& McCarthy 1992, Parker 1995, Oliveira 1997, McCleave \& Arnold 1999). However, mark-recapture experiments are shortterm observations and cannot describe the migratory

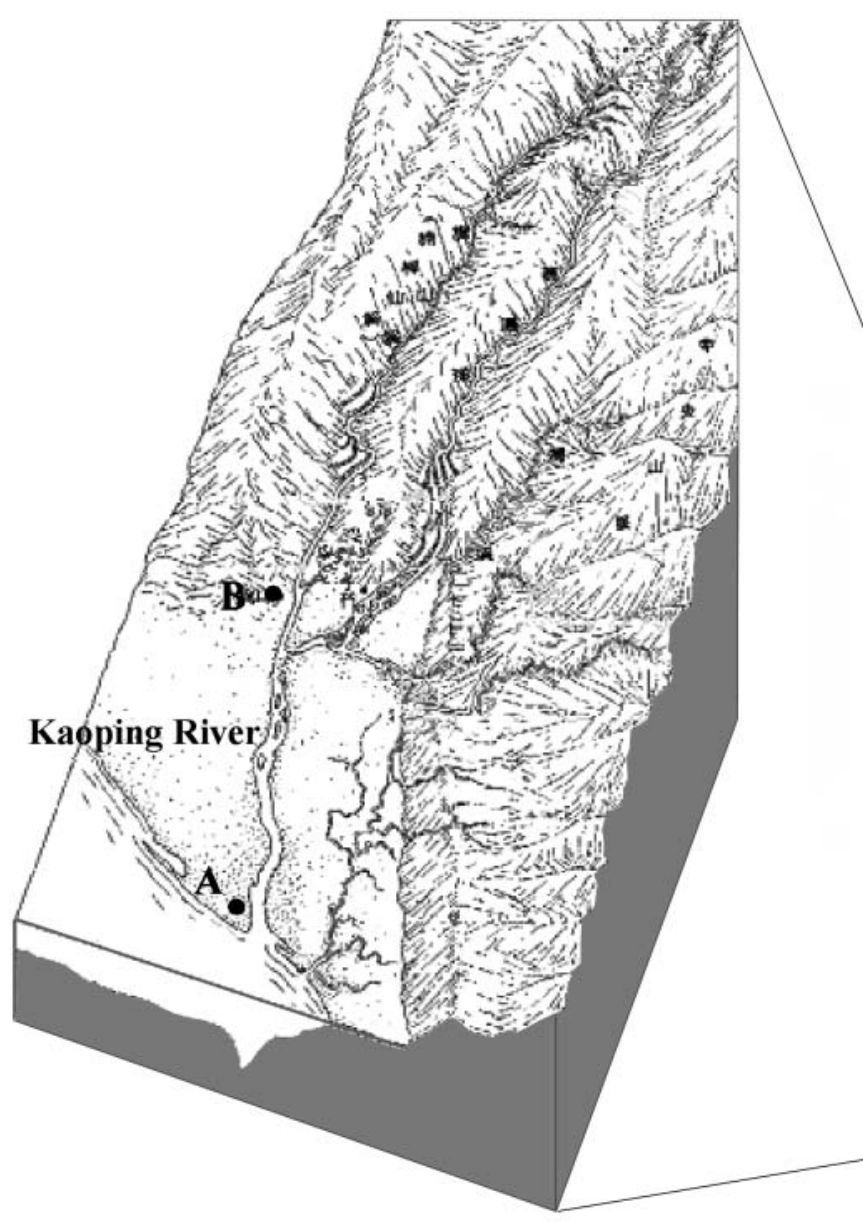

processes during the entire life history of the eel in the river. Hence, most of the migratory behaviors of the eel remained speculative.

The otolith is composed of calcite $\left(\mathrm{CaCO}_{3}\right)$ and a minor organic substance (Degens et al. 1969), which are deposited periodically and remain metabolically inert throughout the fish's life history (Pannella 1971). Strontium ( $\mathrm{Sr}$ ) can substitute for calcium (Ca) in the process of otolith deposition due to a similar ionic charge and ionic radius (Payan et al. 1999). Sr concentrations are 100-fold greater in seawater $\left(8.7 \times 10^{-5} \mathrm{M}\right)$ than in freshwater $\left(9 \times 10^{-7} \mathrm{M}\right)$ (Campana 1999), and $\mathrm{Sr}: \mathrm{Ca}$ ratios in otoliths are positively correlated with the salinity of the ambient water (Tzeng 1996, Kawakami et al. 1998a). Thus, Sr:Ca ratios in otoliths, in combination with age data, have been used to elucidate the migratory environmental history of diadromous fishes (Radtke et al. 1998, 1990), including freshwater eels (Otake et al. 1994, Tzeng \& Tsai 1994, Arai et al. 1997, 1999, Kawakami et al. 1998b, Tzeng et al. 2000b, Jessop et al. 2002).

This study measured the Sr:Ca ratio in otoliths of the Japanese eel in the Kaoping River by the use of an electron probe microanalyzer. In addition, the ages of the eel by counts of otolith annuli were determined. The migratory process of the growth phase yellow eel in the river was revealed by temporal changes in the otolith $\mathrm{Sr}$ :Ca ratio as well as by the age data.

\section{MATERIALS AND METHODS}

Fish collection and sampling area. The Japanese eel Anguilla japonica was collected by eel pot, using earthworms as a lure, in the middle and lower reaches of the 
Kaoping River in SW Taiwan $\left(120^{\circ} 50^{\prime} \mathrm{E}, 22^{\circ} 40^{\prime} \mathrm{N}\right)$ during 1998 and 1999. The bamboo eel pot was about $100 \mathrm{~cm}$ in length and 10 to $15 \mathrm{~cm}$ in diameter. Hundreds of eels were collected from the lower reach near Lin-yuan town and 6 eels from the middle reach near Chi-san town (Fig. 1). The lower reach is an estuary with salinity from 0 to $32 \mathrm{ppt}$. The middle reach is a freshwater habitat approximately $40 \mathrm{~km}$ upriver of the river mouth. The total length (TL) and weight (W) of each eel were measured to the nearest $5 \mathrm{~mm}$ and $0.1 \mathrm{~g}$. Eel condition factors were calculated by W/(TL) ${ }^{3}$. Sexes of the eels were determined by histology of the gonad. Six eels from the middle reach and 58 eels randomly selected from the lower reach were used for $\mathrm{Sr}$ :Ca ratio analysis and age determination, following previous studies (Tzeng \& Tsai 1994, Tzeng et al. 1994).

The Kaoping River is the third largest river in Taiwan and is approximately $171 \mathrm{~km}$ long with a drainage area of $3256 \mathrm{~km}^{2}$. Eels can migrate upriver despite the 2 small dams constructed in the middle and upper reaches. River discharge changes seasonally, with an annual mean discharge of approximately 8455 million $\mathrm{m}^{3}$, with 761 and 7694 million $\mathrm{m}^{3}$ in the dry (winter) and rainy (summer) seasons, respectively.

Otolith preparation and Sr:Ca analysis. The largest pair of the otolith, namely sagittae, of the eel was removed, dried in the air, embedded in epofix resin, ground and polished until the core was exposed. For electron probe microanalysis, the polished otoliths were coated with carbon under a high-vacuum evaporator. $\mathrm{Sr}$ and $\mathrm{Ca}$ concentrations in the otolith were measured from the primordium to the edge of otolith at an interval of 10 or $20 \mu \mathrm{m}$ with an electron beam of $10 \mu \mathrm{m}$ in diameter, using an electron probe microanalyzer (JEOL JXA-8900R). The accelerating voltage was set at $15 \mathrm{kV}$ and probe current at $5 \mathrm{nA}$. The peak concentration of Sr was counted for $90 \mathrm{~s}$ with background measurements for $20 \mathrm{~s}$ on each side. The peak concentration of Ca was counted for $20 \mathrm{~s}$ and each background for $10 \mathrm{~s}$. Strontianite $\left(\mathrm{SrCO}_{3}\right.$ : USNM-R10065) and calcite $\left(\mathrm{CaCO}_{3}\right.$ : USNM-36321) from the Department of Mineral Sciences, National Museum of Natural History, Smithsonian Institution, Washington, DC, were used as the standards to calibrate the concentration of $\mathrm{Sr}$ and $\mathrm{Ca}$ in the eel otolith. The weight percent of $\mathrm{Sr}$ and $\mathrm{Ca}$ in the otolith was calculated. After microchemistry analysis, the otolith was polished to remove the carbon layer, etched for 1 to 2 min with $5 \%$ EDTA to reveal the annual marks for age determination (Fig. 2). The duration of the eel in freshwater and seawater environments was then determined. Measurement procedures for otolith $\mathrm{Sr}$ and $\mathrm{Ca}$ concentrations, age determination and the back-calculation of the lengthat-age of the eel were similar to those of previous studies (Tzeng et al. 1994, 1997, 2000a,b, 2003).
Data analysis. The contingent type for migratory eels was determined according to the level of otolith $\mathrm{Sr}: \mathrm{Ca}$ ratio. The significance of difference in mean total length between the sexes was examined by a $t$-test. The frequency distribution of the contingents in relation to age and developmental stage of the eel was calculated. Differences in frequency distribution of the contingents between yellow and silver stages were tested for significance by the contingency table (Mason et al. 1994). Because the condition factor increased with total length of the eel, the significant difference in condition factors between contingents was tested using analysis of covariance (ANCOVA) (Montgomery 1997).

\section{RESULTS}

\section{Developmental stage, sex and size}

The 6 eels collected from the middle reach of the Kaoping River were all yellow eels: 3 males, 2 females and 1 of undetermined sex. The 59 eels collected from the lower reach comprised 39 yellow eels (32 females and 7 of undetermined sex) and 20 silver eels (4 males and 16 females). Females were more abundant and significantly larger than males ( $t$-test all $\mathrm{p}<0.05$; Table 1).

\section{Temporal change of $\mathrm{Sr}: \mathrm{Ca}$ ratios in the otoliths}

The Sr:Ca ratios in otoliths, before the elver stage, were similar among individuals, indicating that their environmental histories were similar during the marine leptocephalus stage. The ratios increased from

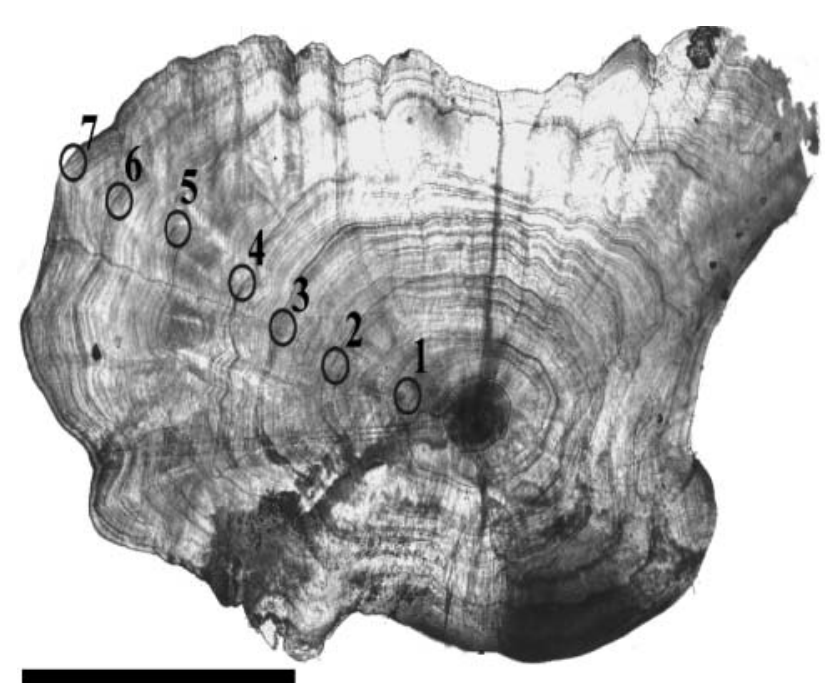

Fig. 2. Anguilla japonica. An otolith. O: elver check; 1 to 7 : annuli. Scale bar $=1 \mathrm{~mm}$ 
Table 1. Anguilla japonica. Mean $( \pm \mathrm{SD})$ total length and weight, by developmental stage and sex, of Japanese eels from the middle and lower reaches of the Kaoping River, SW Taiwan

\begin{tabular}{|c|c|c|c|c|c|}
\hline Location & Stage & Sex & $\mathrm{n}$ & $\begin{array}{l}\text { Total length }(\mathrm{cm}) \\
\text { Mean } \pm \text { SD (range) }\end{array}$ & $\begin{array}{c}\text { Weight (g) } \\
\text { Mean } \pm \text { SD (range) }\end{array}$ \\
\hline Middle reach & Yellow & $\begin{array}{c}\text { Male } \\
\text { Female } \\
\text { Undetermined }\end{array}$ & $\begin{array}{l}3 \\
2 \\
1\end{array}$ & $\begin{array}{c}43.4 \pm 6.5(36.2-49.0) \\
54.7 \pm 21.9(53.1-56.2) \\
36.1\end{array}$ & $\begin{array}{c}117.8 \pm 59.1(54.7-171.9) \\
216.1 \pm 259.8(216.1-259.8) \\
53.2\end{array}$ \\
\hline Lower reach & $\begin{array}{l}\text { Yellow } \\
\text { Silver }\end{array}$ & $\begin{array}{c}\text { Female } \\
\text { Undetermined } \\
\text { Male } \\
\text { Female }\end{array}$ & $\begin{array}{r}32 \\
7 \\
3 \\
16\end{array}$ & $\begin{array}{l}46.0 \pm 5.5(35.5-55.8) \\
40.0 \pm 5.6(32.0-47.0) \\
48.1 \pm 6.2(44.1-47.3) \\
61.0 \pm 8.7(34.1-70.4)\end{array}$ & $\begin{aligned} 132.9 & \pm 64.8(48.9-317.8) \\
77.6 & \pm 38.5(32.8-144.8) \\
179.8 & \pm 36.9(148.0-220.3) \\
367.4 & \pm 163.7(47.1-702.0)\end{aligned}$ \\
\hline
\end{tabular}

8 to $10 \times 10^{-3}$ (Sr ca. $\left.0.3 \mathrm{wt} \%\right)$ in the primordium to a peak of approximately 15 to $18 \times 10^{-3}$ (Sr ca. 0.5 to $0.8 \mathrm{wt} \%$ ) at a distance of 60 to $100 \mu \mathrm{m}$ from the primordium, which corresponded to the stage of metamorphosis from leptocephalus to glass eel. After metamorphosis, the $\mathrm{Sr}$ :Ca ratio decreased to about $7 \times 10^{-3}$ ( $\mathrm{Sr}<0.3 \mathrm{wt} \%$ ) at the elver mark.

The environmental history patterns beyond the elver stage were classified into 3 types. Type 1 (freshwater contingent): all values of the $\mathrm{Sr}$ :Ca ratio from the elver check to the otolith edge of the 6 eels from the middle reach were less than $4 \times 10^{-3}$ (mean \pm SD $1.8 \pm 0.2 \times$ $10^{-3}$, range 0 to $3.73 \times 10^{-3}$; Table 2 ). This indicated that these eels had remained in freshwater since the elver stage. The temporal change in $\mathrm{Sr}$ : Ca ratios in the otolith of a 3 yr old eel from the middle reach is shown in Fig. 3a. Type 1 eels were also found in the lower reach and constituted $14 \%$ of the eel examined with a mean Sr:Ca ratio of $2.2 \pm 0.8 \times 10^{-3}$ (range 0.0 to $4.5 \times$ $10^{-3}$; Table 2). The temporal change in $\mathrm{Sr}$ :Ca ratio in the otolith of Type 1 eel from the lower reach is shown in Fig. 3b. The Sr:Ca ratios of this eel ranged from 0 to $4 \times 10^{-3}(\mathrm{Sr}<0.15 \mathrm{wt} \%)$ between the elver stage and age-5 as a yellow eel.

Type 2 (seawater contingent): 3 of the 58 eels $(5 \%)$ collected in the lower reach were Type 2. The mean $\mathrm{Sr}$ :Ca ratio after the elver stage was $5.5 \pm 1.1 \times 10^{-3}$ (range 2.5 to $8.8 \times 10^{-3}$; Table 2). The higher Sr:Ca ratios in the otoliths of Type 2 eels indicated that they seasonally migrated to highly saline seawater during their stay in the lower reach (Fig. 3c).

Type 3 (estuarine contingent): 47 of the 59 eels $(81 \%)$ collected from the lower reach were Type 3 . The $\mathrm{Sr}$ :Ca ratios after the glass eel stage of Type 3 eels varied considerably among individuals (Table 2). Type 3 measurements differed from Types 1 and 2 in not having consistent low or high Sr:Ca ratios. Fig. 3d-i illustrate the diversified temporal changes of $\mathrm{Sr}$ :Ca ratios in the otoliths of Type 3 eels. For example, Case 1: the Sr:Ca ratio beyond the elver check gradually decreased from $7 \times 10^{-3}$ at the elver check to less than $4 \times 10^{-3}$ at the otolith edge (Fig. 3d,e), indicating that the eel after the elver stage gradually migrated to freshwater. Case 2: the Sr:Ca ratios decreased gradually after the elver check to a low level less than $4 \times 10^{-3}$ at ages- 1 and -2 , and then increased to reach a peak approximately $8.0 \times 10^{-3}$ at age-3. After age-3, it decreased to less than $4 \times 10^{-3}$ again (Fig. 3f). This indicated that the eel migrated into freshwater at ages- 1 and -2, rather than migrating out the river into the seawater at age- 3 and re-invading the river again. Case 3: the $\mathrm{Sr}$ :Ca ratios after the elver check decreased to less than $4 \times 10^{-3}$ from 1 to 4 yr old, then increased to greater than $5 \times 10^{-3}$ thereafter (Fig. 3g,h,i). This indicated that these eels had migrated to freshwater during young yellow eel stage, rather than migrating into seawater, and did not re-entry the river until collected. These phenomena indicated a diversified habitat use and flexible migratory behavior in the yellow phase. Type 3 eels were further divided into

Table 2. Anguilla japonica. Mean Sr:Ca ratios in the otoliths of Japanese eels and the frequency distribution of their life history patterns (Type 1: freshwater resident; Type 2: seawater resident; and Type 3: estuarine resident with (a) a freshwater preference, with more than $1 / 2$ of the measurements of otolith $\mathrm{Sr}$ : $\mathrm{Ca}$ ratios being less than $4 \times 10^{-3}$, and (b) a seawater preference, with more than $1 / 2$ of the measurements of otolith $\mathrm{Sr}$ :Ca ratios eel being greater than $4 \times 10^{-3}$. $\mathrm{Sr}$ :Ca ratios $( \pm \mathrm{SD}$, range) were measured from the elver check to the otolith edge

\begin{tabular}{|c|c|c|c|c|c|c|}
\hline \multirow{3}{*}{$\begin{array}{l}\text { Life } \\
\text { history } \\
\text { pattern }\end{array}$} & \multicolumn{6}{|c|}{ - Sr:Ca ratio (\%o) } \\
\hline & & Middle reac & $\mathrm{h}=$ & & - Lower reach & \\
\hline & n (\%) & Mean \pm SD & Range & n (\%) & Mean \pm SD & Range \\
\hline Type 1 & $6(100)$ & $1.8 \pm 0.2$ & $0-3.73$ & $8(14)$ & $2.2 \pm 0.8$ & $0-4.5$ \\
\hline Type 2 & & & & $3(5)$ & $5.5 \pm 1.1$ & $2.5-8.8$ \\
\hline Tyре 3a & & & & $35(60)$ & $3.1 \pm 1.5$ & $0-9.8$ \\
\hline Type 3b & & & & $12(21)$ & $4.6 \pm 1.5$ & $0.6-10.4$ \\
\hline Total & 6 & & & 58 & & \\
\hline
\end{tabular}



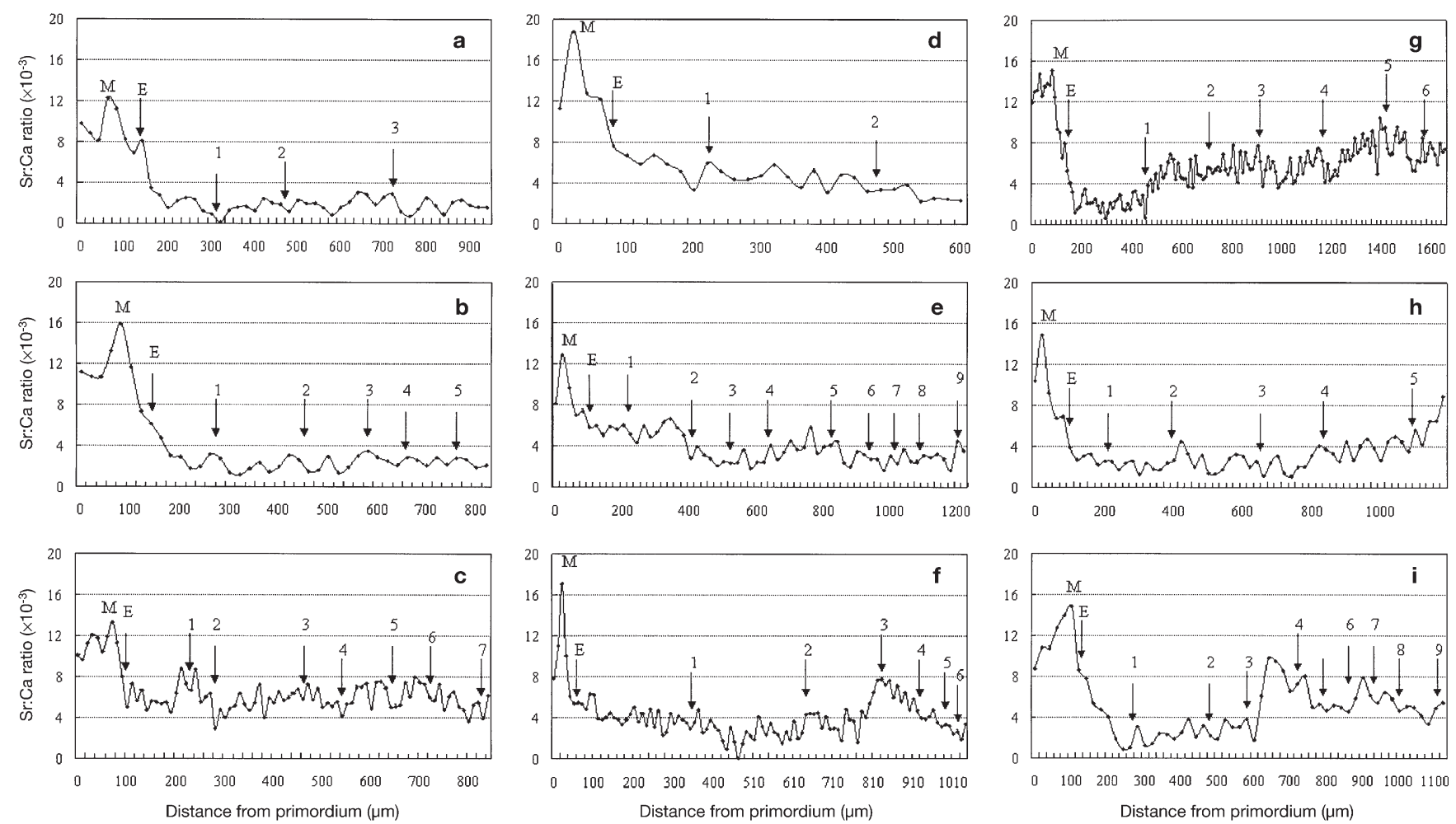

Fig. 3. Anguilla japonica. Temporal changes in the Sr:Ca ratios of eel otoliths from different migratory contingents collected from the middle and lower reaches of the Kaoping River, SW Taiwan. (a,b) Type 1 (freshwater); (c) Type 2 (seawater); (d to i) Type 3 (estuarine). M: metamorphosis from leptocephalus to glass eel; E: elver mark and the numbers the age of the eel. Yellow eel:

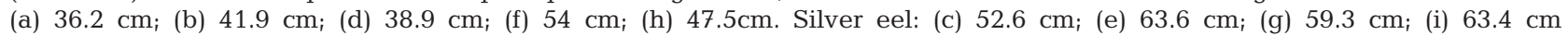

2 subtypes because the estuarine residence of this contingent varied from several months to years. Type 3a (freshwater-favoring contingent): mean $\mathrm{Sr}: \mathrm{Ca}$ ratios less than $3.1 \pm 1.5 \times 10^{-3}$ occurred for more than half of their life span. Conversely, Type 3b (seawater-favoring contingent): mean Sr:Ca ratios greater than $4.6 \pm 1.5 \times$ $10^{-3}$ occurred for more than half of their life span. Eels of Type 3a were approximately 3 times more abundant than Type 3b, indicating that these eels preferred freshwater when they migrated in the estuary (Table 2).

\section{Migratory contingents of yellow and silver eels}

Chi-square test indicated that the frequency distribution of the 3 migratory contingents of female Japanese eels in the Kaoping River was slightly different between yellow and silver eel stages

$$
\chi_{0}^{2}\left(\begin{array}{l}
\mathrm{n}=2 \\
\mathrm{p}=0.05
\end{array}\right)<\chi^{2}<\chi_{0}^{2}\left(\begin{array}{l}
\mathrm{n}=2 \\
\mathrm{p}=0.01
\end{array}\right)
$$

(Table 3). The habitat use of the eel changed with developmental stage, with yellow eel preferring freshwater and silver eel preferring seawater. A similar test was not made for males because of small sample size $(n=7)$.

\section{Migratory behavior in relation to age}

The frequency distribution of the eel migratory contingents by age in the Kaoping River indicated that the proportion of eels using a particular habitat changed with age (Table 4). In the first year, approximately $80 \%$ of eels moved to brackish water. In the second year, $60 \%$ of eels then moved to freshwater, 15 to $20 \%$ of the eels remained in the seawater and $23.9 \%$ of eels remained in brackish water. This tendency was observed for eels younger than 6 yr old. Beyond $6 \mathrm{yr}$ old, the proportion of eels inhabiting brackish water increased. This supported the observation that the eels tended to migrate to freshwater at a young stage.

\section{Comparison of growth rate}

The age-length relationship indicated that growth rate of the female eel did not differ significantly among the 3 migratory contingents (Fig. 4). The adjusted mean of the regression of condition factors on total length of the eel also did not differ statisti- 
Table 3. Contingency table analysis for comparison of the frequency distributions of life history patterns (migratory contingents) for yellow and silver developmental stages of female Japanese eels Anguilla japonica in the lower reach of the Kaoping River. $F_{\mathrm{o}}$ : observed numbers; $F_{\mathrm{e}}$ : expected numbers. For further details on Types 1,2 and 3 refer to Table 2

\begin{tabular}{|lccccccccc|}
\hline \multirow{2}{*}{$\begin{array}{l}\text { Develop- } \\
\text { mental }\end{array}$} & \multicolumn{1}{c|}{ Type 1} & \multicolumn{1}{c|}{ Type 2 } & Type 3 & \multicolumn{2}{c|}{ Total } \\
stage & $F_{\mathrm{o}}$ & $F_{\mathrm{e}}$ & $F_{\mathrm{o}}$ & $F_{\mathrm{e}}$ & $F_{\mathrm{o}}$ & $F_{\mathrm{e}}$ & $F_{\mathrm{o}}$ & $F_{\mathrm{e}}$ \\
\hline Silver eel & 1 & 2 & 3 & 1 & 12 & 12.9 & 16 & 16 \\
Yellow eel & 5 & 4 & 0 & 2 & 26 & 25.1 & 31 & 31 \\
Total & 6 & 6 & 3 & 3 & 38 & 38 & 47 & 47 \\
$\chi_{0}^{2}\left(\begin{array}{l}\mathrm{n}=2 \\
\mathrm{p}=0.05\end{array}\right)=5.991<\chi^{2}=6.722<\chi_{0}^{2}\left(\begin{array}{c}\mathrm{n}=2 \\
\mathrm{p}=0.01\end{array}\right)=9.210$ & & \\
\hline
\end{tabular}

cally among 3 contingents $\left(F_{2,43}=1.73, \mathrm{p}>0.19\right.$; Fig. 5). The sample size for males was too small for comparison.

\section{DISCUSSION}

\section{Discrimination of freshwater and seawater contingents by $\mathrm{Sr}$ :Ca ratios}

The Sr:Ca ratios in fish otoliths are positively correlated to ambient salinities (Tzeng 1996, Kawakami et al. 1998a, Campana 1999, Secor \& Rooker 2000). Thus, the temporal changes of $\mathrm{Sr}$ :Ca ratios in otoliths have been used to discriminate the environmental history of a variety of anadromous, catadromous and amphidromous fishes (Radtke et al. 1988, 1990, Kalish 1990, Secor 1992, Limburg 1995, Tzeng et al. 1997, 2000b, 2002, Tsukamoto et al. 1998, Tsukamoto \& Arai 2001, Jessop et al. 2002). In this study, we found that the $\mathrm{Sr}$ :Ca ratios in otoliths of Japanese eels beyond elver stage ranged from less than $4 \times 10^{-3}$ to greater than $10 \times 10^{-3}$. The Sr:Ca ratios from the elver stage to the otolith edge for 6 eels from the middle reach of the Kaoping River were consistently lower than $4 \times 10^{-3}$. The middle reach was approximately $40 \mathrm{~km}$ from the river mouth, completely free from tidal influence and a purely freshwater environment. Consequently, a $\mathrm{Sr}: \mathrm{Ca}$ ratio of $4.0 \times 10^{-3}$ in the otoliths of yellow-phase eels could be used as a criterion to discriminate residence in freshwater ( $\mathrm{Sr}$ :Ca ratio less than $4 \times 10^{-3}$ ) from residence in estuarine or coastal habitats ( $\mathrm{Sr}: \mathrm{Ca}$ ratio greater than $4 \times 10^{-3}$ ).

\section{Implication of otolith $\mathrm{Sr}: \mathrm{Ca}$ ratios for the migratory environmental history}

Based on the temporal changes in otolith $\mathrm{Sr}: \mathrm{Ca}$ ratios, the migratory and environmental history of Japanese eels in the yellow eel stage was classified into 3 patterns. For Type 1, the otolith Sr:Ca ratios were consistently lower than $4 \times 10^{-3}$, indicating that the eel entered the river as an elver and continued to reside in freshwaters until capture (Fig. 3a,b). For Type 2, the otolith Sr:Ca ratios were greater than $4 \times 10^{-3}$, indicating that the eel did not enter the freshwater but resided in the coastal or estuarine waters (Fig. 3c). For Type 3, the otolith $\mathrm{Sr}: \mathrm{Ca}$ ratios ranged from 0 to $10 \times 10^{-3}$, indicating that the eels had migrated between freshwater and seawater. The use of temporal changes in otolith $\mathrm{Sr}$ : Ca ratios to reconstruct the entire migratory history of the eel in the river may be superior to marking experiments that can only trace a shortterm migratory history.

\section{Migratory behavioral hypothesis for yellow eel}

Elvers are freshwater-oriented and move upriver during onshore migration (Creutzberg 1961, Tesch 1977, Tzeng 1985). Thus, the Sr:Ca ratios in eel otoliths should gradually decrease during the upstream migration, becoming lower than $4 \times 10^{-3}$ after the elver stage. However, we found that some eels have a $\mathrm{Sr}$ :Ca ratio higher than $4 \times 10^{-3}$ after the elver stage. This indicated that a segment of the elvers did not migrate upstream but stayed in the estuary (Table 2, Fig. 3). Some of them even stayed in the estuary for several years until seaward spawning migration at the silver stage (Table 4). The migratory behavior of the eel in

Table 4. Frequency distributions, by age and migratory contingent, for female Japanese eels Anguilla japonica in the lower reach of the Kaoping River. For further details on Types 1, 2 and 3 refer to Table 2

\begin{tabular}{|c|c|c|c|c|c|c|c|c|c|c|c|}
\hline \multirow{2}{*}{$\begin{array}{l}\text { Migratory } \\
\text { contingents }\end{array}$} & \multirow[b]{2}{*}{ Age } & \multirow[b]{2}{*}{$0-1$} & \multirow[b]{2}{*}{$1-2$} & \multirow[b]{2}{*}{$2-3$} & \multirow[b]{2}{*}{$3-4$} & \multicolumn{2}{|c|}{ Frequency (\%) } & \multirow[b]{2}{*}{$6-7$} & \multirow[b]{2}{*}{$7-8$} & \multirow[b]{2}{*}{$8-9$} & \multirow[b]{2}{*}{$9-10$} \\
\hline & & & & & & $4-5$ & $5-6$ & & & & \\
\hline Type 1 & & 0 & 60.9 & 50 & 46.7 & 43.2 & 52.2 & 37.5 & 28.6 & 0 & 0 \\
\hline Type 2 & & 19.6 & 15.2 & 10.9 & 20.0 & 24.3 & 21.7 & 25.0 & 28.6 & 50.0 & 0 \\
\hline Type 3 & & 80.4 & 23.9 & 39.1 & 33.3 & 32.4 & 26.1 & 37.5 & 42.9 & 50.0 & 100 \\
\hline No. of fish & & 46 & 46 & 46 & 45 & 37 & 23 & 16 & 7 & 2 & 1 \\
\hline
\end{tabular}




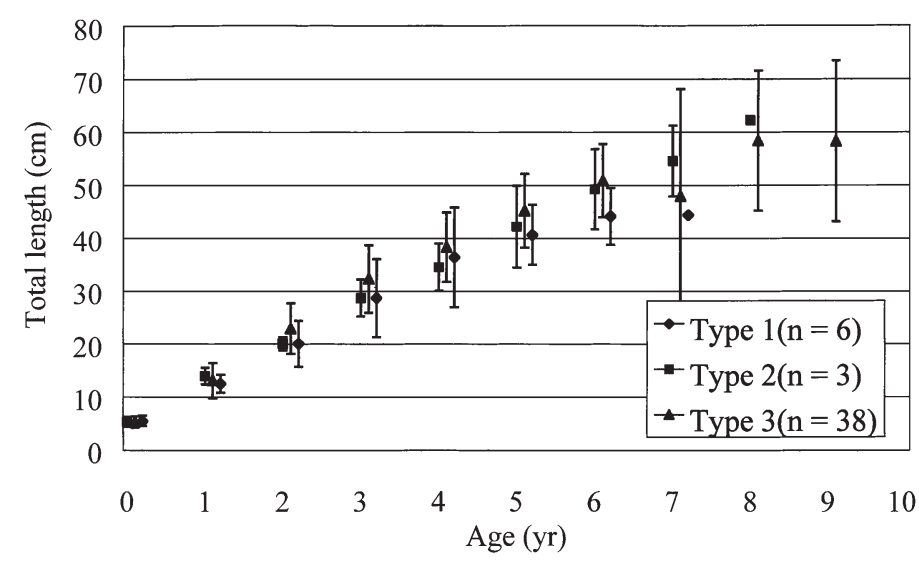

Fig. 4. Anguilla japonica. Comparisons of the mean $( \pm \mathrm{SD})$ total length of female eels, by age and migratory contingents. For further details on Types 1, 2 and 3 refer to Table 2

the growth phase yellow stage is not completely understood. Some have proposed that the yellow eel has a restricted home range and returns to its initial habitat after foraging outside its territory (Gunning \& Shoop 1962, Bianchini et al. 1982, Bozeman et al. 1985, Ford \& Mercer 1986, Oliveira 1997). However, the migratory environmental history of the eel, as revealed by temporal changes in otolith $\mathrm{Sr}$ :Ca ratios, did not support the restricted home range behavior for all eels. The migratory behavior of yellow stage or growth phase eels was flexible, as has been observed for European (Tzeng et al. 1997, 2000b), Japanese (Tsukamoto et al. 1998, Tsukamoto \& Arai 2001, Tzeng et al. 2003) and American eels (Jessop et al. 2002). Some Japanese eels preferred freshwater in the elver stage, but migrated to brackish water as yellow eels (Fig. 3g); in contrast, some eels stayed in freshwater for more than $1 \mathrm{yr}$ from elver to yellow eel stage

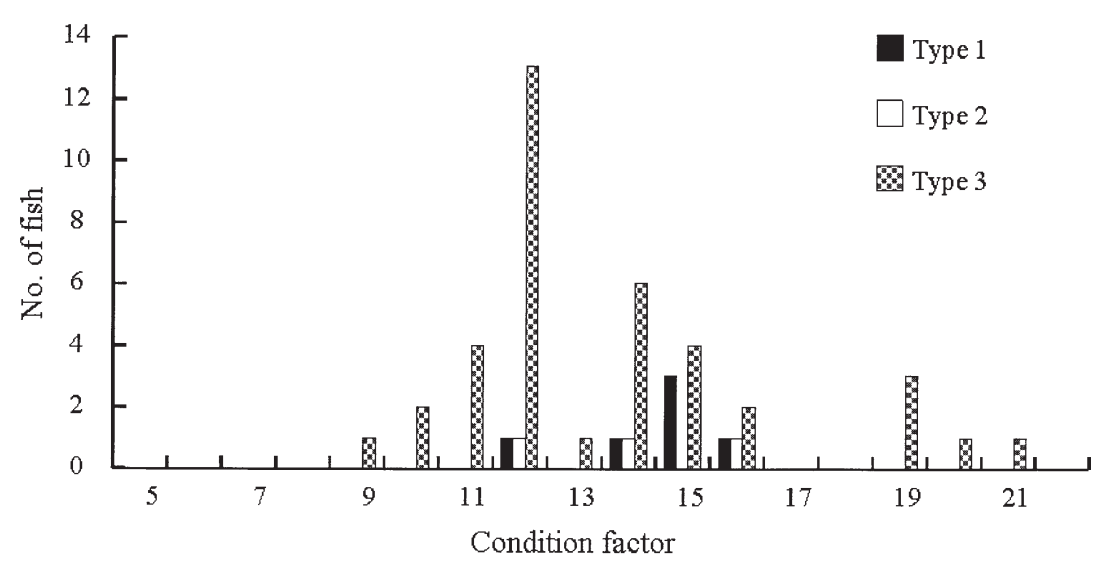

Fig. 5. Anguilla japonica. Frequency distribution of the condition factors of female migratory eels. For further details on Types 1, 2 and 3 refer to Table 2
(Fig. 3f,h,i). Some eels even remained in brackish water from the elver stage until seaward movement during the spawning migration (e.g. Fig. 3c), while others delayed entrance to freshwater (e.g. Fig. 3d,e). Previous studies hypothesized that the glass eel's preference for freshwater is due to the lower osmotic concentration of the animal's body composition (Parry 1966). The body fluid concentration is higher in young yellow eels, which preferred brackish water with a salinity of $18 \%$ (Schulz 1975). However, the temporal change in eel otolith $\mathrm{Sr}: \mathrm{Ca}$ ratios indicated that the migratory behavior of yellow eels was much diversified among individuals. Our study does not completely support the hypothesis of a limited home range for the eel. Eel migratory behavior was diversified rather than a simple migration to freshwater (Tables $2 \& 4$, Fig. 3). Catadromous eel migration from a low productivity tropical ocean to high productivity tropical or temperate freshwater may provide maximum evolutionary fitness for foraging (Gross 1987). Except for food availability, environmental factors such as river flooding may influence the eel migration. The discharge of the Kaoping River is extremely unstable. In the dry season (winter), discharge is only $1 / 10$ that in the wet season (summer). Less discharge may reduce food availability and lead to an unstable eel habitat. During the dry season, eels may be compelled to migrate downstream, perhaps explaining why the estuarine contingents were dominant in the eel population (Table 2). Although yellow American eels in brackish waters had faster growth rates than yellow eels from freshwater areas (Harrell \& Loyacano 1982, Hansen \& Eversole 1984, Helfman et al. 1984), the condition factor and growth curve of the Japanese eel in the Kaoping River did not differ significantly among migratory contingents. This indicated that the growth rate of the eel did not completely depend on the habitat. In addition to food availability and habitat carrying capacity, the genetics, physiology, homing behavior, temperature, population density, and intra- and inter-specific competition may potentially influence the migratory behavior of the eel. Further study is needed to better understand the migratory behavior of the eel in the river.

In conclusion, most eels oriented to the freshwater of the upriver habitat at a young age but tended to move to the estuary when older. During upstream migration, a segment of elver population remained in the estuary and higher saline coastal waters until their silver phase. This implies that Japanese eels in the river have a great degree of plasticity in behavior and habitat use. 
Acknowledgements. The National Science Council (Project No. NSC89-2311-B002-077) provided financial support for this study. We thank Messrs. C. W. Chang, Y. S. Han, S. F. Lin, J. T. Ho and G. H. Cheng for field work, and Mr. G. H. Cheng for otolith preparation and data processing. We also gratefully acknowledge Mr. Brian M. Jessop for reviewing the manuscript.

\section{LITERATURE CITED}

Arai T, Otake T, Tsukamoto K (1997) Drastic changes in otolith microstructure and microchemistry accompanying the onset of metamorphosis in the Japanese eel Anguilla japonica. Mar Ecol Prog Ser 161:17-22

Arai T, Limbong D, Otake T, Tsukamoto K (1999) Metamorphosis and inshore migration of tropical eels, Anguilla spp., in the Indo-Pacific. Mar Ecol Prog Ser 182:283-293

Berg R (1986) Field studies on eel (Anguilla anguilla) in Lake Constance: tagging effects causing retardation of growth. Vie Milieu 36:285-286

Bianchini M, Sorensen PW, Winn HE (1982) Stima dell'abbondanza e schemi di movimento a breve raggio della anguilla Americana, Anguilla rostrata (LeSueur) (Pisces, Apodes), nel Narrow River, Rhode Island, USA. Nat Sicil 6(Suppl 4):269-277

Bozeman EL, Helfman GS, Richardson T (1985) Population size and home range of American eels in a Georgia tidal creek. Trans Am Fish Soc 114:821-825

Campana (1999) Chemistry and composition of fish otoliths: pathways, mechanism and applications. Mar Ecol Prog Ser 188:263-297

Cheng PW, Tzeng WN (1996) Timing of metamorphosis and estuarine arrival across the dispersal range of the Japanese eel Anguilla japonica. Mar Ecol Prog Ser 131:87-96

Clark J (1968) Seasonal movements of striped bass contingents of Long Island Sound and the New York Bight. Trans Am Fish Soc 97:320-343

Creutzberg F (1961) On the orientation of migrating elvers (Anguilla vulgaris Turt.) in a tidal area. Neth J Sea Res 1: 257-338

Degens ET, Deuser WG, Haedrich RL (1969) Molecular structure and composition of fish otoliths. Mar Biol 2:105-113

Ford TE, Mercer E (1986) Density, size distribution and home range of American eels, Anguilla rostrata, in a Massachusetts salt marsh. Environ Biol Fish 17:309-314

Gross MR (1987) The evolution of diadromy in fishes. Am Fish Soc Symp 1:14-25

Gunning GE, Shoop CR (1962) Restricted movements of the American eel, Anguilla rostrata (LeSueur), in freshwater streams, with comments on growth rate. Tulane Stud Zool 9:265-272

Hansen RA, Eversole AG (1984) Age, growth, and sex ratio of American eel in brackish-water portions of a South Carolina river. Trans Am Fish Soc 113:744-749

Harrell RM, Loyacano HA (1982) Age, growth and sex ratio of the American eel in the Cooper River, South Carolina. Proc Annu Conf SE Assoc Fish Wildl Agencies 34(1980): 349-359

Helfman GS, Stoneburner DL, Bozeman EL, Christian PA, Whalen R (1983) Ultrasonic telemetry of American eel movements in a tidal creek. Trans Am Fish Soc 112: $105-110$

Helfman GS, Bozeman EL, Brothers EB (1984) Comparison of American eel growth rates from tag returns and lengthage analyses. US Fish Bull 82:519-522

Jessop BM, Shiao JC, Iizuki Y, Tzeng WN (2002) Migratory behaviour and habitat use by American eels Anguilla rostrata as revealed by otolith microchemistry. Mar Ecol Prog Ser 233:217-229

Kalish (1990) Use of otolith microchemistry to distinguish the progeny of sympatric anadromous and non-anadromous salmonids. US Fish Bull 88:657-666

Kawakami Y, Mochioka N, Morishita K, Tajima K, Nakagawa H, Toh H, Nakazona A (1998a) Factors affecting otolith strontium/calcium ratios in Anguilla japonica elvers. Environ Biol Fish 52:299-303

Kawakami Y, Mochioka N, Morishita K, Toh H, Nakazono A (1998b) Determination of the freshwater mark in otoliths of Japanese eel elvers using microstructure and Sr/Ca ratios. Environ Biol Fish 53:421-427

LaBar GW, Facey DE (1983) Local movements and inshore population sizes of American eels in Lake Champlain, Vermont. Trans Am Fish Soc 112:111-116

Liew PKL (1982) Impact of the eel ladder on the upstream migrating eel (Anguilla rostrata) population in the St. Lawrence River at Cornwall: 1974-1978. In: Loftus KH (ed) Proc 1980 N Am Eel Conf. Ontario Fish Tech Rep Ser, Vol 4. Ministry of Natural Resources, Ontario, p 17-22

Limburg KE (1995) Otolith strontium traces environmental history of subyearling American shad Alosa sapidissima. Mar Ecol Prog Ser 119:25-35

Limburg KE, Wickstöm H, Svedäng H, Elfman M, Kristianson P (2002) Do stocked freshwater eel migrate? Evidence from the Baltic systems 'yes'. Am Fish Soc Symp (33 in press)

Mason RD, Lind DA, Marchal WG (1994) Statistics, 4th edn. Saunders College Publishing, Orlando, FL

McCleave JD, Arnold GP (1999) Movements of yellow- and silver-phase European eels (Anguilla anguilla L.) tracked in the western North Sea. ICES J Mar Sci 56:510-536

McGovern P, McCaethy TK (1992) Local movements of freshwater eels (Anguilla anguilla L.) in western Ireland. In: Priede IG, Swift SM (eds) Wildlife telemetry: remote sensing and monitoring of animals. Ellis Horwood, Chichester, p 319-327

Montgomery DC (1997) Design and analysis of experiments, 4 th edn. John Wiley \& Sons, New York

Oliveira K (1997) Movement and growth rates of yellowphase American eels in the Annaquatucket River, Rhode Island. Trans Am Fish Soc 126:638-646

Otake T, Ishii T, Nakahara M, Nakamura R (1994) Drastic changes in otolith strontium/calcium ratios in leptocephali and glass eels of Japanese eel Anguilla japonica. Mar Ecol Prog Ser 112:189-193

Pannella G (1971) Fish otolith: daily growth layers and periodical patterns. Science 173:1124-1127

Parker SJ (1995) Homing ability and home range of yellowphase American eels in a tidally dominated estuary. J Mar Biol Assoc UK 75:127-140

Parry G (1966) Osmotic adaptation in fishes. Biol Rev 41: 392-444

Payan P, Edeyer A, De Pontual H, Borelli G, Boeuf G, MayerGostan N (1999) Chemical composition of saccular endolymph and otolith in fish inner ear: lack of spatial uniformity. Am J Physiol Regul Integr Comp Physiol 277: R123-R131

Radtke RL, Kinize RA III, Folsom SD (1988) Age at recruitment of Hawaiian freshwater gobies. Environ Biol Fish 23: 205-213

Radtke RL, Townsend DW, Folsom SD, Morrison MA (1990) Strontium:calcium concentration ratios in otoliths of herring larvae as indicators of environmental histories. Environ Biol Fish 27:51-61 
Sang TK, Chang HY, Chen TC, Hui CF (1994) Population structure of the Japanese eel Anguilla japonica. Mol Biol Evol 11:250-260

Schulz D (1975) Salinitätspräferenzen bei Glasaalen und jungen Gelbaalen (Anguilla anguilla). Helgol Wiss Meeresunters 27:199-210

Secor DH (1992) Application of otolith microchemistry analysis to investigate anadromy in Chesapeake Bay striped bass Morone saxatilis. US Fish Bull 90:798-806

Secor DH (1999) Specifying divergent migrations in the concept of stock: the contingent hypothesis. Fish Res 43:13-43

Secor DH, Rooker JR (2000) Is otolith strontium a useful scalar of life cycles in estuarine fishes? Fish Res 46:359-371

Tesch FW (1977) The eel: biology and management of anguillid eels. Chapman \& Hall, New York

Tsukamoto K (1992) Discovery of the spawning area for Japanese eel. Nature 356:789-791

Tsukamoto K, Arai T (2001) Facultative catadromy of the eel Anguilla japonica between freshwater and seawater habitats. Mar Ecol Prog Ser 220:265-276

Tsukamoto K, Nakai I, Tesch WV (1998) Do all freshwater eels migrate? Nature 396:635-636

Tzeng WN (1985) Immigration timing and activity rhythms of the eel, Anguilla japonica, elvers in the estuary of northern Taiwan with emphasis on environmental influences. Bull Jpn Soc Fish Oceanogr 47/48:11-28

Tzeng WN (1990) Relationship between growth rate and age at recruitment of Anguilla japonica elvers in a Taiwan estuary as inferred from otolith growth increments. Mar Biol 107:75-81

Editorial responsibility: Otto Kinne (Editor),

Oldendorf/Luhe, Germany
Tzeng WN (1996) Effects of salinity and ontogenetic movements on strontium:calcium ratios in the otoliths of the Japanese eel, Anguilla japonica Temminck \& Schlegel. J Exp Mar Biol Ecol 199:111-122

Tzeng WN, Tsai YC (1994) Changes in otolith microchemistry of the Japanese eel, Anguilla japonica, during its migration from the ocean to the rivers of Taiwan. J Fish Biol 45 671-683

Tzeng WN, Wu HF, Wickström H (1994) Scanning electron microscopic analysis of annulus microstructure in otolith of European eel Anguilla anguilla. J Fish Biol 45: 479-492

Tzeng WN, Severin KP, Wickström H (1997) Use of otolith microchemistry to investigate the environmental history of European eel Anguilla anguilla. Mar Ecol Prog Ser 149: $73-81$

Tzeng WN, Lin HR, Wang CH, Xu SN (2000a) Differences in size and growth rates of male and female migrating Japanese eels in Pearl River, China. J Fish Biol 57: $1245-1253$

Tzeng WN, Wang CH, Wickström H, Reizenstein M (2000b) Occurrence of the semi-catadromous European eel Anguilla anguilla (L.) in Baltic Sea. Mar Biol 137:93-98

Tzeng WN, Iizuka Y, Shiao JC, Yamada Y, Oka HP (2003) Identification and growth rates comparison of divergent migratory contingents of Japanese eel (Anguilla japonica). Aquaculture 216:77-86

Westin L (1990) Orientation mechanisms in migrating European silver eel (Anguilla anguilla): temperature and olfaction. Mar Biol 106:175-179

Submitted: May 22, 2002; Accepted: August 28, 2002

Proofs received from author(s): November 28, 2002 